\title{
PENGELOLAAN HUBUNGAN PUSAT DAN DAERAH DALAM PENANGANAN PANDEMI COVID-19
}

\section{MANAGEMENT OF CENTRAL GOVERNMENT AND REGIONAL GOVERNMENT RELATIONS IN HANDLING OF PANDEMIC COVID-19}

\author{
Bambang Ariyanto ${ }^{1}$ \\ ${ }^{1}$ Dosen Hukum Pemerintahan, FH Universitas Hang Tuah Surabaya \\ Jl. Arif Rahman Hakim No. 150 Surabaya, Propinsi Jawa Timur, 60111 \\ Email: bambang.ariyanto@hangtuah.ac.id
}

\begin{abstract}
So far there is no standard formula in handling Covid-19 Pandemic. Almost all countries try to solve the Covid-19 Pandemic problem in different ways and strategies. Some succeed, some don't. Indonesia is one of the countries trying to deal with the Covid-19 Pandemic with a Large-Scale Social Limitation strategy (PSBB) which is based on Law No. 6 of 2018 on Quarantine and Government Regulation No. 21 of 2020. This policy choice is an anticipatory step to respond to some regional policies that tend to run individually. Regions seem to have a "taste" to control their territory according to their wishes. This phenomenon raises the issue of whether the basic principles used in the management of the Central Government and Regional Governments in handling this Covid-19 pandemic. This is also related to how the direction of Law No. 23 of 2014 concerning the Regional Government has implications for the management of the central and regional relations. The research method is a normative juridical research method with a statutory approach and conceptual approach. The result is that the basic principles in managing the relationship between the Central Government and the Regional Government are based on decentralization. However, along with the new regulation in Law No. 23 of 2014 concerning the Regional Government, the management of this relationship has shifted towards centralization. This affects the relationship model between the Central Government and Regional Governments which theoretically places Regional Governments more as The Agency Model.
\end{abstract}

Keywords: Relationship between the central government and local governments, Law No. 23 of 2014, decentralization, pandemic covid-19

\section{Intisari}

Selama ini tidak ada rumus baku dalam penanganan Pandemi Covid-19. Hampir semua negara mencoba menyelesaikan persoalan Pandemi Covid-19 ini dengan cara dan strategi yang berbeda-beda. Ada yang berhasil, ada pula yang tidak. Indonesia adalah salah satu negara yang berusaha menangani Pandemi Covid-19 dengan strategi Pembatasan Sosial Berskala Besar (PSBB) yang berlandaskan 
pada Undang-Undang No 6 Tahun 2018 tentang Karantina dan Peraturan Pemerintah No 21 Tahun 2020. Pilihan kebijakan ini sebenarnya sebagai langkah antisipatif merespon sejumlah kebijakan daerah yang cenderung berjalan sendirisendiri. Daerah seakan mempunyai "selera" untuk mengendalikan wilayahnya sesuai keinginannya. Fenomena ini menimbulkan persoalan mengenai apakah prinsip dasar yang digunakan dalam pengelolaan Pemerintah Pusat dan Pemerintah Daerah dalam penanganan pandemi Covid-19 ini. Hal ini berkaitan juga bagaimana arah UU No 23 Tahun 2014 tentang Pemerintahan Daerah berimplikasi terhadap pengelolaan hubungan pusat dan daerah tersebut. Metode penelitian adalah metode penelitian yuridis normatif dengan pendekatan perundang-undangan dan pendekatan konseptual. Hasilnya prinsip dasar dalam pengelolaan hubungan Pemerintahan Pusat dan Pemerintahan Daerah sebenarnya berbasis desentralisasi. Namun, seiring adanya pengaturan baru dalam UU No 23 Tahun 2014 tentang Pemerintahan Daerah, pengelolaan hubungan ini bergeser ke arah sentralisasi. Hal ini berpengaruh terhadap model hubungan antara Pemerintah Pusat dan Pemerintah Daerah yang secara teoritis lebih banyak menempatkan Pemerintah Daerah sebagai The Agency Model.

Kata Kunci: Hubungan pemerintah pusat dan pemerintah daerah, UU Nomor 23 Tahun 2014, desentralisasi, pandemi covid-19

\section{PENDAHULUAN}

Desain konstitusional hubungan antara Pemerintah Pusat dan Pemerintah Daerah di Indonesia dibangun atas dasar prinsip negara kesatuan. ${ }^{1}$ Prinsip negara kesatuan menekankan kekuasaan tertinggi atas segenap urusan negara ialah pemerintah pusat tanpa adanya suatu delegasi atau pelimpahan kekuasaan kepada pemerintah daerah (local government). ${ }^{2}$ Dalam negara kesatuan, tanggung jawab pelaksanaan tugas-tugas pemerintahan pada dasarnya tetap berada di tangan pemerintah pusat.

Dari perspektif susunan negara, karakteristik negara kesatuan itu bersifat tunggal. Artinya, negara kesatuan itu tidak tersusun dari beberapa negara, melainkan hanya terdiri atas satu negara, sehingga tidak ada negara di dalam negara. ${ }^{3}$ Meski begitu, dalam pelaksanaan pemerintahan, pemerintah pusat memiliki wewenang untuk menyerahkan sebagian kekuasaannya kepada pemerintahan daerah berdasarkan hak otonomi. Walaupun pada tahap akhir, kekuasaan tertinggi tetap ada di tangan pemerintah pusat. Model negara kesatuan semacam ini biasa disebut dengan sistem desentralisasi. Sebaliknya, bagi pemerintah pusat yang tidak menyerahkan sebagian kekuasaannya kepada daerah lazim disebut sistem sentralisasi.

Secara konstitusional, perubahan terhadap Pasal 18 Undang-Undang Dasar Negara Republik Indonesia Tahun 1945 (UUD 1945) sebenarnya sudah memberi

1 Pasal 1 ayat (1) Undang-Undang Dasar Negara Republik Indonesia Tahun 1945 menegaskan Negara Indonesia adalah Negara Kesatuan yang Berbentuk Republik.

2 Ni;matul Huda, Hukum Tata Negara Indonesia, Edisi Revisi, Rajawali Pers, Jakarta, Cetakan Keenam, 2011., hlm. 92.

${ }^{3}$ Edie Toet Hendratno, Negara Kesatuan, Desentralisasi, dan Federalisme, Graha Ilmu, Yogyakarta, 2009., hlm. 45. 
kejelasan mengenai paradigma baru dan arah politik pemerintahan daerah. Dari arah politik itu menunjukkan bahwa negara kesatuan yang diterapkan adalah negara kesatuan dengan sistem desentralisasi. Meski begitu, dalam perkembangannya hingga saat ini arah desentralisasi itu selalu bergerak pada titik keseimbangan yang berbeda. Jika diibaratkan sebagai bandul, maka pergerakan bandul ini selalu bergerak pada dua sisi, yakni pusat dan daerah. Atau dalam bahasa lain, pergerakannya ke arah sentralisasi atau desentralisasi.

Persoalannya adalah tarik-menarik pengelolaan hubungan pemerintah pusat dan pemerintah daerah ini mempunyai dinamika yang unik. Hubungan ini dibangun atas landasan peraturan perundang-undangan yang mengatur tentang Pemerintahan Daerah. Setiap kali peraturan perundang-undangan tentang Pemerintahan Daerah berubah, maka berubah juga pola hubungan yang dibangun antara pusat dan daerah. Hal ini menunjukkan bahwa dalam konteks pengelolaan hubungan pusat dan daerah, para perumus otonomi daerah di Indonesia masih mencari pola dan design yang tepat dalam mengelola keadaan khusus dan keragaman yang ada di setiap daerah.

Pengelolaan hubungan pusat dan daerah pun menjadi "kabur dan kurang jelas", ketika Indonesia menghadapi situasi yang disebut sebagai Kedaruratan Kesehatan Masyarakat. ${ }^{4}$ Kondisi kedaruratan kesehatan ini muncul atas meluasnya Corona Virus Disease 2019 (Covid-19) yang tersebar di seluruh wilayah Indonesia. Penyebaran virus yang cukup cepat dan massif ini membuat sejumlah daerah melakukan langkah-langkah pencegahan. Bentuk pencegahannya pun bermacam-macam. Ada daerah yang mengambil kebijakan menutup akses keluar masuk kota selama empat bulan, menegaskan daerahnya sebagai Kejadian Luar Biasa (KLB), dan menutup jalur penerbangan serta jalur laut. ${ }^{5}$ Namun,

4 Presiden telah mengeluarkan Keputusan Presiden Nomor 11 Tahun 2020 tentang Kedaruratan Kesehatan Masyarakat Corona Virus Disease 2019 (Covid-19).

5 Dari catatan yang dihimpun, ada 8 (delapan) daerah yang menerapkan sejumlah kebijakan untuk melindungi wilayah daerahnya sendiri. Adapun kebijakan dari pemerintah daerah itu antara lain: (1) Walikota Tegal Dedy Yon Supriyono mengambil kebijakan menutup akses keluar masuk kota selama empat bulan ke depan. Kebijakan itu berlaku mulai 30 Maret - 30 Juli 2020; (2) Gubernur Bali, Wayan Koster mengeluarkan surat imbauan dengan No 45/Satgascovid19/III/2020 pada 23 Maret 2020. Isinya menghimbau warga Bali agar tetap bekerja di rumah dan belajar di rumah, mengurangi aktivitas keluar rumah. Surat ini berlaku sampai dengan 30 Maret 2020 dan akan menyesuaikan perkembangan situasi di pusat dan daerah; (3) Wali Kota Tasikmalaya Budi Budiman mengambil langkah penutupan wilayahnya setelah muncul lima kasus positif Covid-19 di daerahnya. Kebijakan ini berlaku pada 31 Maret 2020; (4) Wali Kota Solo FX Hadi Rudyantmo mendeklarasikan Covid-19 di daerahnya sebagai Kejadian Luar Biasa (KLB). Bentuk KLB-nya dengan meliburkan sekolah, menunda gelajaran acara dengan massa besar, membatalkan car free day, dan penutupan destinasi wisata; (5) Gubernur Papa Lukas Enembe menutup akses orang dan penumpang dari laut dan udara kecuali angkutan barang dan makanan pasca temuan adanya 7 (tujuh) warga Papua yang terinfekso Covid-19. Gubernur juga menerapkan status siaga darurat mulai 17 Maret 2020 - 17 April 2020; (6) Gubernur Maluku Murad Ismail mengeluarkan Surat Keputusan Gubenrur No 148 Tahun 2020 tentang Status Darurat Bencana Non Alam Virus Corona (Covid-19). Status itu ditetapkan sejak 22 Maret 2020 dengan menutup jalur penerbangan dan pelayaran selama 14 hari berlaku; (7) Pemerintah Kota Banda Aceh melakukan local lockdown untuk menekan penyebaran virus corona, terutama di wilayah yang terdapat pasien positif Covid-19; (8) Gubernur Provinsi Sumatera Barat Irwan Prayitno menerapkan kebijakan memperketat arus masuk di seluruh perbatasan provinsi Sumbar. 
langkah pencegahan ini ternyata tidak berbanding lurus dengan kebijakan dari pemerintah pusat. ${ }^{6}$

Dalam hal bantuan sosial, kerumitan juga terjadi antara pusat dan daerah. Bantuan sosial yang disiapkan oleh pemerintah pusat ternyata tidak bersatu padu dengan pemerintah daerah. Data yang ada di daerah tidak sinkron dengan data di pusat. Akibatnya, sejumlah gejolak terjadi di daerah. Ada warga yang kemampuan ekonominya menengah justru dapat bantuan, sedangkan masyarakat yang memang miskin tidak mendapatkan bantuan sosial. ${ }^{7}$

Pemerintah Daerah pantas khawatir atas penanganan Pandemi Covid-19 ini. Meskipun pemerintah pusat memberikan norma, standar, pedoman dan kriteria dalam penanganan Covid-19, namun persoalan yang dihadapi justru bertumpu pada pemerintah daerah. Mulai dari penanganan pasien positif covid-19 di rumah sakit daerah, masyarakat yang terdampak, persoalan sosial yang timbul akibat pandemi ini, semuanya terjadi di daerah. Di sisi lain, ruang gerak pemerintah daerah juga terbatas karena pengaturan penanganan Pandemi Covid-19 menitikberatkan pada kebijakan pemerintah pusat.

Dari latar belakang di atas, rumusan masalah yang penulis angkat dalam kajian ini mengenai apakah prinsip dasar yang digunakan dalam pengelolaan hubungan Pemerintah Pusat dan Pemerintah Daerah dalam penanganan pandemi Covid-19 ini. Persoalan ini penting untuk dijawab mengingat dalam penanganan pandemi Covid-19 ini yang dibutuhkan bukanlah kesimpangsiuran, tapi kesatuan gerak, kesatuan sikap dan sinergitas pengelolaan pemerintahan. Arah kebijakan ini yang berjalan terpadu akan memberikan rasa aman dan nyaman bagi masyarakat baik di level daerah, maupun tingkat nasional.

Untuk menjawab rumusan masalah di atas, penulis menggunakan metode penelitian yuridis normatif. Penelitian yuridis normatif adalah penelitian yang mengacu pada norma-norma hukum yang terdapat dalam peraturan perundangundangan dan putusan pengadilan yang berkaitan dengan Pemerintahan Daerah, khususnya tentang pengelolaan hubungan pusat dan daerah. Pendekatan permasalahan yang digunakan dalam penelitan ini, meliputi : pendekatan

6 Presiden Joko Widodo mengingatkan kepada pemerintah daerah untuk menerapkan kebijakan yang tidak melenceng dengan pemerintah pusat. Tindakan pemerintah pusat untuk mengatasi pandemi Corona Virus Disease (Covid-19) sudah sesuai dengan peraturan perundangundangan, khususnya Undang-Undang No 6 Tahun 2018 tentang Kekarantinaan Kesehatan (UU No 6/2018). Presiden juga meminta kepada Menteri Dalam Negeri menegur kepala daerah yang menutup akses jalan sehingga menghambat distribusi bahan pokok. Lihat di Media Indonesia, Daerah Diminta Tidak Melenceng, Kamis, 2 April 2020, hlm.1.

${ }^{7}$ Kekisruhan penyaluran bantuan sosial terjadi di hampir semua daerah. Di Ibu Kota, bantuan bahan pangan dari Pemerintah Provinsi DKI Jakarta nyasar ke kawasan elit Kelapa Gading dan anggota parlemen provinsi. Di Jawa Barat, sejumlah bantuan tidak datang serempak, sebab ada sembilan jenis bantuan sosial yang bergulir dari masing-masing instansi baik daerah maupun dari pusat. Padahal dana yang bergulir ke masyarakat cukup besar. Pemerintah Pusat misalnya mengalokasikan tambahan anggaran dana sebesar Rp 110 triliun untuk program yang menyasar keluarga miskin, lalu Pemerintah Daerah menyiapkan Rp 25,34 triliun untuk program serupa. Bahkan Dana Desa juga menyiapkan bantuan langsung tunai senilai Rp 22,4 triliun. Lihat di Majalah Tempo, Buruk Data, Bansos Digelontor, Edisi 4-11 Mei 2020, hlm.55 
konseptual (conceptual approach) dan pendekatan perundang-undangan (statute approach). ${ }^{8}$

\section{PEMBAHASAN}

\section{Kedudukan Pemda dalam Negara Kesatuan}

Dalam perspektif negara kesatuan, kedudukan pemerintah daerah mempunyai arti penting dalam penyelenggaraan fungsi utama pemerintahan. Menurut Rasjid, fungsi utama pemerintahan menekankan pada tiga hal yakni fungi pengaturan, fungsi pelayanan dan fungsi pemberdayaan. Ketiga fungsi ini merupakan tugas pemerintahan yang ditujukan pada kepentingan umum (public service) yang dijalankan oleh alat pemerintahan. Fungsi-fungsi ini juga tidak akan berjalan maksimal apabila distribusi urusan-urusan pemerintahan tersentralisasi pada pemerintah pusat.

Sarundajang mengemukakan ada 4 (empat) alasan urgensi pemerintahan daerah bagi Negara Kesatuan Republik Indonesia. Pertama, alasan sejarah. Kedua, alasan situasi dan kondisi wilayah. Ketiga, alasan keterbatasan pemerintah. Keempat, alasan politik dan psikologis. ${ }^{9}$

Secara historis, eksistensi pemerintah daerah telah dikenal sejak masa zaman kerajaan. Pembangunan sistem pemerintahan dimulai dari desa, kampung, kelurahan, hingga sampai ke tingkat puncak pemerintahan. Bahkan ada pemerintahan yang berbasiskan persekutuan masyarakat adat yang keberadaannya tetap diakui oleh pemerintah kolonial pada saat itu. ${ }^{10}$ Hal yang menonjol dari pengelolaan pemerintahan daerah di era kerajaan dan kolonial adalah kecenderungan sentralisasi kekuasaan pada pusat pemerintahan.

Begitu kuatnya pengaruh historis inilah yang menjadi dasar bagi Moh. Yamin dan Soepomo dalam menyampaikan gagasannya tentang Pemerintahan Daerah pada waktu penyusunan Rancangan Undang-Undang Dasar di Badan Penyelidik Usaha Persiapan Kemerdekaan Indonesia (BPUPKI). Dasar pemikiran kedua tokoh inilah yang mengilhami lahirnya Pasal 18 UUD 1945 (sebelum perubahan). ${ }^{11}$

\footnotetext{
8 Peter Mahmud Marzuki, Penelitian Hukum, Prenada Media Group, Cetakan Ke-7, November 2011, hal. 22

${ }^{9}$ S.H. Sarundajang, Arus Balik Kekuasaan Pusat ke Daerah, Sinar Harapan, Jakarta, 1999, hlm.21-25.

${ }^{10}$ Persekutuan masyarakat adat ini disebut sebagai "Zelbestuurende lansdchappen" seperti Desa di Jawa, Nagari di Minangkabau, Huta/Huria dan lain-lainnya untuk beberapa pulau di daerah Hindia Belanda. Untuk Desa di Jawa diatur dengan Inlandsche Gemmente-ordonantie (S.83/1906) atau IGO, untuk masyarakat adat di luar Jawa diatur dengan Inlandsche Gemeenteordonantie Buitengewesten (S.507/1931) atau IGOB. Untuk desa-desa di Jawa, kemudian diatur lebih lanjut dengan "Desa Ordonantie" (S.356/1941) yang tidak sempat dilaksanakan karena terjadinya Perang Dunia II. Lihat di Syaukani dkk, Otonomi Daerah dalam Negara Kesatuan, Pustaka Pelajar, Yogyakarta, Cetakan IX, 2012, hlm.51

11 Ada tiga esensi yang terkandung dari ketentuan Pasal 18 UUD 1945 adalah: Pertama, keberadaan daerah otonomi dalam penyelenggaraan pemerintahan daerah yang didasarkan pada asas desentralisasi. Kedua, satuan pemerintahan tingkat daerah menurut UUD 1945 dalam penyelenggaraannya dilakukan dengan "“"memandang dan mengingati dasar permusyawaratan dalam sistem pemerintahan negara. Ketiga, Pemerintahan daerah juga harus disusun dan diselenggarakan dengan "memandang dan mengingati hak-hak asal-usul dalam daerah-daerah
} 
Kedua, alasan situasi dan kondisi wilayah. Secara geografis, Indonesia adalah negara yang memiliki 17.504 pulau dengan total luas wilayah darat hingga 1.922.570 kilometer persegi dan luas perairannya 3.257.483 kilometer persegi. Garis pantainya mencapai 54.716 kilometer. Luasnya wilayah Negara Indonesia ini mempunyai konsekuensi logis terhadap lahirnya berbagi suku dengan adat istiadat, kebiasaan, kebudayaan dan ragam bahasa daerahnya masing-masing. Termasuk juga kondisi keadaan dan kekayaan alam serta potensi permasalahan yang ada di daerah memiliki kekhususan tersendiri.

Ciri khas bangsa Indonesia yang mengedepankan keanekaragaman sesuai slogan Bhinneka Tunggal Ika inilah yang perlu dikelola secara baik agar mempunyai potensi pendapatan nasional. Untuk itu, pengelolaan pemerintahan yang efektif dan efisien menjadi pilihan agar mampu menjawab dinamika tantangan global yang begitu cepat.

Ketiga, alasan keterbatasan pemerintah. Dalam menjalankan tugas pemerintahan, pemerintah pusat menyadari bahwa ada banyak urusan pemerintahan yang tidak bisa sepenuhnya ditangani oleh pusat. Urusan pemerintahan ini harus didistribusikan kepada pemerintah daerah melalui pemberian kesempatan untuk mengatur dan mengurus rumah tangganya sendiri (otonomi daerah). Hal ini sesuai dengan asas yang dikemukakan oleh Solly Lubis bahwa dalam suatu Negara Kesatuan segenap urusan negara tidak dibagi antara Pemerintah Pusat (Central Government) dengan Pemerintah Daerah (Local Government) sedemikian rupa. Urusan negara kesatuan itu tetap merupakan suatu kebulatan (eenheid) dan bahwa pemegang kekuasaan tertinggi di Negara itu adalah Pemerintah Pusat. ${ }^{12}$

Keempat, alasan politis dan psikologis. Pemberian otonomi kepada pemerintahan daerah merupakan langkah strategis yang bersifat politis dan psikologis. Langkah ini dilakukan untuk mencegah disintegrasi bangsa. Pemerintahan Orde Baru telah membangun sistem hukum, sosial dan politik yang mengabaikan peran pemerintahan daerah. Melalui Undang-Undang Nomor 5 Tahun 1974 (UU No 5/1974) konfigurasi politik cenderung ke arah sentralisasi kekuasaan yang dibungkus dengan dekonsentrasi. Prinsip otonomi yang riil dan seluas-luasnya diganti dengan prinsip otonomi yang nyata dan bertanggung jawab. ${ }^{13}$ Hal ini selaras dengan arah Garis-garis Besar Haluan Negara (GBHN)

yang bersifat istimewa. Lihat Ni'matul Huda, Otonomi Daerah; Filosofi, Sejarah Perkembangan dan Problematika, Pustaka Pelajar, Yogyakarta, hlm.3.

12 M. Solly Lubis, Pergeseran Garis Politik dan Perundang-undangan Mengenai Pemerintahan Daerah, Alumni, Bandung, 1975, hlm.16-17

${ }^{13}$ Dalam penjelasan dari UU No 5/1974 dinyatakan bahwa "istilah seluas-luasnya" tidak lagi dipergunakan karena berdasarkan pengalaman selama ini istilah tersebut ternyata dapat menimbulkan kecenderungan pemikiran yang dapat membahayakan keutuhan Negara Kesatuan dan tidak serasi dengan maksud dan tujuan pemberian otonomi kepada Daerah sesuai dengan prinsip-prinsip yang digariskan oleh GBHN. Ada beberapa karakteristik menonjol dari UU 5/1974: (1) wilayah negara dibagi ke dalam Daerah besar dan kecil yang bersifat otonom atau administratif saja; (2) Pemerintahan daerah diselenggarakan secara bertingkat, yaitu Daerah Tingkat I, Daerah Tingkat II sebagai daerah otonom, dan kemudian Wilayah Administratif berupa Propinsi, Kabupaten/Kotamadya, dan Kecamatan. Daerah otonom tingkat lebih tinggi berhak memberikan pengawasan terhadap Daerah yang lebih rendah. Hubungan antara Daerah Tingkat I dan Tingkat II bersifat hirarkis di dalam hampir semua aspek pemerintahan; (3) Dewan Perwakilan Rakyat 
yang menyatakan bahwa otonomi daerah harus : (a) serasi dengan pembinaan politik dan kesatuan bangsa; (b) dapat menjamin hubungan yang serasi antara Pemerintah Pusat dan Daerah atas dasar keutuhan Negara Kesatuan; (c) dapat menjamin perkembangan dan pembangunan daerah.

Implementasi dari penerapan ketentuan UU Pemerintahan Daerah di era Orde Baru justru menimbulkan persoalan di daerah. Pasca jatuhnya pemerintahan Orde Baru, tuntutan dari sejumlah Daerah untuk memisahkan diri dari Negara Kesatuan justru semakin kuat. Hal ini terjadi karena Daerah-daerah tersebut menuntut kewenangan dan pembagian hasil dari sumber daya alam yang selama ini dinikmati oleh pemerintah pusat. Untuk itulah, pemerintah pasca reformasi berusaha menjaga rumah besar Indonesia sebagai negara kesatuan dengan pemberian otonomi daerah, termasuk kebijakan otonomi khusus di Daerah Istimewa Aceh dan Provinsi Irian Jaya.

Sejumlah alasan mengenai urgensi dari pemerintahan daerah dalam Negara Kesatuan semakin dikuatkan dengan perubahan Pasal 18 UUD 1945. Amandemen terhadap UUD 1945 telah mengubah substansi dan struktur dari Pasal 18 UUD 1945, yang awalnya hanya satu pasal kini menjadi tiga pasal, mulai dari Pasal 18, Pasal 18A, dan Pasal 18B. Selain itu, pasal yang mengatur mengenai Pemerintahan Daerah ini memuat paradigma dan arah politik pemerintahan daerah yang baru, dengan sejumlah prinsip-prinsip, antara lain; ${ }^{14}$ (a) Prinsip daerah mengatur dan mengurus sendiri urusan pemerintahan menurut asas otonomi dan tugas pembantuan; ${ }^{15}$ (b) Prinsip menjalankan otonomi seluas-luasnya; ${ }^{16}$ (c) Prinsip kekhususan dan keragaman daerah; ${ }^{17}$ (d) Prinsip mengakui dan menghormati kesatuan masyarakat hukum adat beserta hak-hak tradisionalnya; ${ }^{18}$ (e) Prinsip mengakui dan menghormati pemerintahan daerah yang bersifat khusus dan istimewa; ${ }^{19}$ (f) Prinsip badan perwakilan dipilih langsung dalam suatu pemilihan umum $;{ }^{20}$ (g) Prinsip hubungan pusat dan daerah harus dilaksanakan secara selaras dan adil. ${ }^{21}$

Mengacu pada ketentuan konstitusional tersebut, maka penerapan otonomi daerah dilakukan dengan mendesentralisasikan kewenangan yang selama ini tersentralisasi di tangan pemerintah pusat. Desentralisasi kewenangan ini sangat penting untuk menjamin agar proses integrasi nasional dapat dipelihara dengan

Daerah (DPRD) baik Tingkat I maupun Tingkat II dan Kotamadya merupakan bagian dari Pemerintah Daerah; (4) Peranan Menteri Dalam Negeri dalam penyelenggaraan pemerintahan daerah dapat dikatakan bersifat sangat eksesif atau berlebih-lebihan yang diwujudkan dengan melakukan pembinaan langsung terhadap Daerah; (5) UU ini memberikan tempat yang sangat terhormat dan sangat kuat kepada Kepala Wilayah ketimbang kepada Kepala Daerah; (6) Daerah sama sekali tidak memiliki keleluasaan dalam menggali sumber daya keuangan dengan memanfaatkan sumber daya alam yang dimiliki oleh Daerah. Sumber daya alam itu sepenuhnya diatur dan dikuasai oleh Pemerintah Pusat. Lihat di Syaukani, Op.Cit, hlm. 143-150.

${ }^{14}$ Ni'matul Huda, Op.Cit, hlm.308-310.

${ }^{15}$ Pasal 18 ayat (2) UUD 1945

${ }^{16}$ Pasal 18 ayat (5) UUD 1945

${ }^{17}$ Pasal 18A ayat (1) UUD 1945

${ }^{18}$ Pasal 18B ayat (2) UUD 1945

${ }^{19}$ Pasal 18 ayat (1) UUD 1945

${ }^{20}$ Pasal 18 ayat (3) UUD 1945

${ }^{21}$ Pasal 18A ayat (2) UUD 1945 
sebaik-baiknya dan daerah dapat mengurus rumah tangganya sendiri. ${ }^{22}$ Menurut C.V. Van Der Pot, desentralisasi ketatanegaraan dibagi dua macam yakni : (1) Desentralisasi teritorial yakni pelimpahan kekuasaan untuk mengatur dan mengurus rumah tangganya dari daerah masing-masing; (2) Desentralisasi Fungsional yakni pelimpahan kekuasaan untuk mengatur dan mengurus sesuatu atau beberapa kepentingan tertentu. ${ }^{23}$

Ciri yang utama dari desentralisasi teritorial ini baik di lapangan perundang-undangan maupun lapangan pemerintahan adalah adanya : (1) Otonomi (autonomie); dan (2) medebewind atau zelfbestuur. Karakter desentralisasi teritorial inilah yang dianut oleh Indonesia dalam penyelenggaraan pemerintahan. ${ }^{24}$ Hal ini senada dengan Philipus M.Hadjon yang menyatakan desentralisasi mengandung makna bahwa wewenang untuk mengatur dan mengurus urusan pemerintahan tidak semata-mata dilakukan oleh pemerintah pusat, dilakukan juga oleh satuan-satuan pemerintahan yang lebih rendah, baik dalam bentuk satuan teritorial maupun fungsional. ${ }^{25}$

Agenda desentralisasi pada prinsipnya adalah pembagian kewenangan secara vertikal. Dalam kerangka otonomi daerah, desentralisasi juga harus berjalan beriringan dengan pembagian kewenangan secara horizontal, atau biasa disebut dekonsentrasi. ${ }^{26}$ Kedua hal ini, baik desentralisasi maupun dekonsentrasi mempunyai sifat yang sama, yakni membatasi kekuasaan dan berperan sangat penting dalam menciptakan iklim kekuasaan yang makin demokratis berdasar atas hukum. ${ }^{27}$ Esensi otonomi daerah tidak hanya pada pengalihan kewenangan dari

22 B.C. Smith membedakan tujuan desentralisasi berdasarkan kepentingan nasional (pemerintah pusat) dan kepentingan pemerintah daerah. Bagi pemerintah pusat tujuan desentralisasi adalah : (1) political education (pendidikan politik); (2) to provide training in political leadership (untuk latihan kepemimpinan); (3) to create political stability (untuk menciptakan stabilitas politik). Sedangkan bagi pemerintah daerah, tujuannya adalah : (1) untuk mewujudkan political equality yakni membuka partisipasi masyarakat dalam berbagai aktivitas politik di tingkat lokal; (2) local accountability yakni peningkatan kemampuan pemerintah daerah dalam memperhatikan hak-hak komunitasnya, termasuk hak untuk mengontrol pelaksanaan pemerintahan daerah; (3) local responsiveness, yakni meningkatkan akselerasi pembangunan sosial dan ekonomi di daerah. Lihat B.C. Smith, Decentralization: The Territorial Dimension of The State, London Asia Publishing House, 1985, hlm. 18-19.

${ }^{23}$ Tjahya Supriatna, Sistem Administrasi Pemerintahan di Daerah, Penerbit Bumi Aksara, Jakarta, 1992, hlm.1-2.

${ }^{24}$ Ridwan HR, Hukum Administrasi di Daerah, FH UII Press, Yogyakarta, 2009, hlm.16.

25 Philipus M.Hadjon, Pengantar Hukum Administrasi Indonesia, Penerbit Gajah Mada University Press, Yogyakarta, 1993, hlm. 111.

${ }^{26}$ Dekonsentrasi adalah pelimpahan sebagian dari kewenangan Pemerintah Pusat pada alat-alat Pusat yang ada di daerah atau pelaksanaan urusan pemerintahan pusat, yang tidak diserahkan kepada satuan pemerintahan daerah, oleh organ pemerintahan pusat yang ada di daerah. Melalui dekonsentrasi inilah terbentuk wilayah administratif yang mempunyai ciri-ciri: (a) urusanurusan yang diselenggarakan ialah urusan-urusan pusat yang ada di daerah; (b) pemerintahannya dilaksanakan oleh pejabat-pejabat pusat yang ditempatkan di daerah; (c) dalam melaksanakan urusan-urusan tersebut hanya bersifat penyelenggaraan administratif belaka; (d) hubungan dengan pemerintah pusat atau pemerintah lokal administratif tingkat atasnya yaitu sebagai atasanbawahan; (e) semua penyelenggaraannya dibiayai oleh pusat yang diambil dari sumber keuangan pusat. Lihat Ridwan, Op.Cit, hlm.19-21

27 Jimly Asshiddiqie,Konstitusi dan Konstitusionalisme Indonesia, Sinar Grafika, Jakarta, hlm. 227. 
Pemerintah Pusat ke Pemerintah Daerah, tetapi juga pengalihan kewenangan dari pemerintahan ke masyarakat.

Bentuk desentralisasi yang lain, kata Bagir Manan, adalah otonomi dan tugas pembantuan. Tugas pembantuan merupakan bagian dari desentralisasi dan tidak ada perbedaan pokok antara otonomi dengan tugas pembantuan. Perbedaannya hanya pada tingkat kebebasan dan kemandirian. Pada otonomi, kebebasan dan kemandirian itu penuh meliputi baik asas maupun cara menjalankannya. Sedangkan pada tugas pembantuan, kebebasan dan kemandirian hanya terbatas pada cara menjalankannya. Ateng Syafrudin menyatakan dasar pertimbangan pelaksanaan asas tugas pembantuan adalah : (a) keterbatasan kemampuan pemerintah dan atau pemerintah daerah; (b) sifat sesuatu urusan yang sulit dilaksanakan dengan baik tanpa mengikutsertakan pemerintah di daerah; (c) perkembangan dan kebutuhan masyarakat, sehingga sesuatu pemerintahan akan lebih berdaya guna dan berhasil guna apabila ditugaskan kepada pemerintah daerah. $^{28}$

\section{Desentralisasi Kunci Hubungan Pusat-Daerah}

Pengelolaan hubungan Pemerintah Pusat dan Pemerintah Daerah dalam kerangka otonomi daerah itu sebenarnya mengacu pada prinsip dasar yang utama yakni Desentralisasi. Hal ini telah ditegaskan dalam Pasal 18 UUD 1945. Ateng Syafrudin mencermati secara seksama bahwa ketentuan Pasal 18 UUD 1945 sebenarnya hanya mengatur masalah desentralisasi. ${ }^{29}$ Bagir Manan menyatakan Pasal 18 UUD 1945 hanya mengatur otonomi berdasarkan pembagian teritorial, tidak terdapat petunjuk bahwa Pasal 18 mengatur prinsip daerah wilayah administrasi atau dekosentrasi disamping desentralisasi atau otonomi. ${ }^{30}$ Philipus M. Hadjon menyimpulkan bahwa prinsip yang terkandung dalam Pasal 18A merupakan prinsip hubungan antara Pemerintah Pusat dan Pemerintah Daerah, yang meliputi : (a) Prinsip Hubungan wewenang pada ayat (1); (b) Prinsip hubungan keuangan, pelayanan umum dan pemanfaatan sumber daya pada ayat (2). ${ }^{31}$

Desentralisasi dan otonomi merupakan dua istilah yang mempunyai pengertian berbeda. Istilah Otonomi lebih cenderung berada dalam aspek politikkekuasaan negara, sedangkan desenstralisasi menekankan pada aspek administrasi

\footnotetext{
${ }^{28}$ Ateng Syafrudin, Pasang Surut Otonomi Daerah, Penerbit Bina Cipta, Bandung, 1985, hlm., 45 .

29 Ateng Syafrudin, Titik Berat Otonomi Daerah pada Daerah Tingkat II dan Perkembangannya, Mandar Maju, Bandung, 1991, hlm.19-22.

30 Bagir Manan, Hubungan Pusat dan Daerah Menurut UUD 1945, Pustaka Sinar Harapan, Jakarta, 1995, hlm. 234.

${ }^{31}$ Berkaitan dengan adanya hubungan pelayanan umum, Philipus M. Hadjon menyatakan ketidaksepahamannya. Menurutnya, Pasal 18A ayat (2) tidak mengamanatkan secara khusus pengaturan hubungan pelayanan umum dalam bentuk undang-undang, sedangkan makna pelayanan umum sangat penting. Hal in diamini oleh Edie Toet Hendratno yang menyatakan pelayanan umum merupakan konkret pelaksanaan fungsi negara yang diemban oleh pemerintah terutama pemerintah daerah, sehingga diperlukan suatu pengaturan khusus tentang hubungan pelayanan umum dalam rangka penyelenggaraan otonomi daerah. Lihat Edie Toet Hendratno, Op.Cit, hlm.171
} 
negara. Kedua aspek ini baru menemukan titik temu ketika dilihat dari perspektif pembagian kekuasaan (sharing of power) karena saling berkaitan erat dan tidak dapat dipisahkan. ${ }^{32}$ Jika berbicara mengenai otonomi daerah, maka menyangkut pula seberapa besar wewenang untuk menyelenggarakan urusan pemerintahan yang telah diberikan sebagai wewenang daerah. Begitu pula ketika membicarakan desentralisasi, maka dengan sendirinya membicarakan otonomi. Esensi desentralisasi adalah pengotonomian, yakni proses penyerahan kepada satuan pemerintahan yang lebih rendah untuk mengatur dan mengelola urusan pemerintahan tertentu sebagai urusan rumah tangganya. ${ }^{33}$

Dalam kerangka pengelolaan pemerintahan, desentralisasi bukanlah antitesis atau alternatif dari sentralisasi. Desentralisasi dan sentralisasi tidak dilawankan (tidak dikotomis), melainkan keduanya merupakan sub-sub sistem dalam kerangka organisasi negara bangsa (nation-state). ${ }^{34}$ Penegasan dari hal ini bisa dilihat dalam Pasal 18 ayat (5) yang menyatakan bahwa : Pemerintahan Daerah menjalankan otonomi yang seluas-luasnya, kecuali urusan pemerintahan pusat. Urusan-urusan tersebut secara akademik, biasa disebut sebagai urusan absolut. Yakni urusan-urusan bidang tertentu yang secara mutlak (absolut) tidak diserahkan kepada daerah dalam rangka Desentralisasi, namun urusan-urusan sepenuhnya (100\%) diatur dan diselenggarakan oleh unsur pemerintah pusat.

Jimly Asshiddiqie ${ }^{35}$ mengatakan bahwa secara umum desentralisasi dapat dibedakan dalam tiga pengertian. Pertama, desentraliasi dalam arti dekonsentrasi yang merupakan pelimpahan beban tugas atau beban kerja dari pemerintah pusat di daerah tanpa diikuti oleh pelimpahan kewenangan untuk mengambil keputusan; Kedua, desentralisasi dalam arti pendelegasian kewenangan berisi penyerahan kekuasaan untuk mengambil keputusan dari pemerintah pusat kepada pemerintah daerah atau unit organisasi pemerintah daerah yang berada di luar jangkauan kembali pemerintah pusat; Ketiga, desentralisasi dalam arti devolusi atau penyerahan fungsi dan kewenangan merupakan penyerahan fungsi pemerintahan dan kewenangan pusat kepada pemerintah daerah. Dengan penyerahan itu, pemerintah daerah menjadi otonom dan tanpa dikontrol oleh pemerintah pusat yang telah menyerahkan hal itu kepada daerah. Bertitik tolak dari pemikiran Jimly Asshiddiqie tersebut, Indonesia tidak menganut desentralisasi dalam arti dekonsentrasi ataupun desentralisasi dalam arti devolusi. Indonesia menganut desentralisasi dalam arti pendegelasian kewenangan dimana pemerintah pusat menyerahkan kekuasaan untuk mengambil keputusan kepada pemerintah daerah.

Di negara kesatuan, tidak mungkin terdapat materi urusan pemerintahan (fungsi) yang hanya dilakukan secara desentralisasi tanpa sentralisasi. Artinya, selalu terdapat wewenang mengatur pusat untuk materi urusan-urusan pemerintahan, sekalipun diselenggarakan dengan atau tanpa melalui asas

\footnotetext{
${ }^{32}$ Ibid, hlm.63

${ }^{33}$ Sirajudin, et al, Hukum Administrasi Pemerintahan Daerah, Setara Press, Malang, 2016, hlm.3

34 Rahyunir Rauf, Asas Penyelenggaraan Pemerintah Daerah: Dekonsentrasi, Desentralisasi, dan Tugas Pembantuan, Zanafa Publishing, 2018, Hlm.103

35 Jimly Asshiddiqie, Pengantar Ilmu Hukum Tata Negara, Rajawali Pers, Jakarta, 2012. Hlm. 295.
} 
desentralisasi. dengan kata lain, pemerintah pusat secara eksklusif dapat memiliki wewenang mengatur dan mengurus secara mutlak, dan tidak pernah terjadi di daerah otonom memiliki satu wewenang yang eksklusif. Kewenangan yang diberikan kepada pemerintahan daerah adalah kewenangan eksekutif yang dimiliki oleh Presiden, bukan kewenangan penyelenggara negara lainnya. Oleh karena itu, Presiden memiliki kewenangan untuk melakukan pengawasan terhadap penyelenggaraan pemerintahan daerah provinsi dan kabupaten/kota. ${ }^{36}$

Penerapan desentralisasi bagi pemerintah memberikan banyak keuntungan. Dari studi yang dikemukakan oleh Rondinelli, Roy Bahl, Cheeme dan Sabir, desentralisasi tugas-tugas pemerintahan dan pembangunan akan memperoleh manfaat antara lain: (a) Efisiensi. Penerapan desentralisasi melalui pendegalasian kewenangan/urusan-urusan mempengaruhi penghematan pembiayaan bagi pemerintah pusat karena tidak mesti melaksanakan tugas-tugasnya secara langsung di daerah; (b) Efektivitas. Dalam pelaksanaan asas desentralisasi, ujung tombak yang utama adalah unsur pemerintahan daerah yakni aparat-aparat pemerintah di daerah. Unsur pemerintahan daerah ini dapat mengetahui secara cepat terhadap situasi dan masalah serta berupaya mencari solusi pemecahannya; (c) Memungkinkan melakukan inovasi. Langkah ini mendorong daerah untuk melakukan inovasi, menggali potensi-potensi baru yang mendukung dan memperlancar pelaksanaan urusan pemerintahan. Hal ini terjadi karena kepercayaan yang diberikan pemerintah pusat kepada pemerintah daerah; (d) meningkatkan motivasi moral, komitmen dan produktivitas. Harapan dari manfaat ini adalah aparat pemerintah dapat meningkatkan kesadaran moral untuk senantiasa memelihara kepercayaan yang diberikan oleh pemerintah pusat, lalu menimbulkan komitmen untuk melaksanakan urusan-urusan yang dipercayakan pada mereka. ${ }^{37}$

Analisis Hubert J.B. Allen terhadap pemerintahan lokal di Benua Eropa, Amerika, Afrika dan Asia terhadap pelaksanaan sistem desentralisasi menyimpulkan paling sedikit ada 13 manfaat dan keuntungan dari kebijakan desentralisasi dalam proses penyelenggaran sistem pemerintahan daerah. ${ }^{38}$ Dari ketiga belas manfaat itu, yang menarik bagi Hubert adalah sistem desentralisasi dapat meningkatkan rasa solidaritas sosial dan bukan menimbulkan "disintegrasi bangsa atau separasi". 39

Implikasi logis dari berlakunya kebijakan desentralisasi, kewenangan dari urusan pemerintah daerah (khususnya kabupaten/kota) semakin luas, sedangkan kewenangan dari urusan pemerintah pusat semakin mengecil. Untuk mencari keseimbangan itulah, pemerintah pusat seringkali memainkan peran dalam siklus

36 Kausar Ali Saleh, Mengelola Hubungan Pemerintahan Pusat dengan Pemerintahan Daerah yang Efektif dan Efisien Dalam Politik Desentralisasi, Jurnal Ilmu Budaya, Vol.40, No.55, Maret 2017, hlm. 6294.

${ }^{37}$ Ibid.

${ }^{38}$ Hubert J.B Allen mengemukakan 13 Keuntungan dan manfaat desentralisasi itu antara lain: (1) Kelancaran; (2) kecepatan; (3) Kenyamanan; (4) Koordinasi; (5) Penghematan; (6) Realitas Ekonomi; (7) Realitas Sosial; (8) Pemerataan Manfaat; (9) Partisipasi; (10) Pendidikan Politik; (11) Solidaritas Nasional; (12) Penyebaran Kewenangan; (13) Mobilisasi sumber daya. Rahyunir Rauf, Op.Cit, hlm 115

${ }^{39}$ Ibid. 
kebijakan pembangunan melalui fungsi dekonsentrasi. Hal ini bertujuan agar daerah yang menyelenggarakan fungsi desentralisasi tidak memiliki ego berlebihan dalam memikirkan daerahnya sendiri. ${ }^{40}$ Disinilah upaya untuk menjaga harmonisasi dan sinergitas antara pemerintahan pusat dan pemerintahan daerah dalam pelaksanaan pemerintahan menjadi penting.

Bagir Manan menyatakan ada empat macam dasar-dasar hubungan antara Pusat dan Daerah dalam kerangka desentralisasi. Empat dasar itulah adalah: (a) Dasar permusyawaratan dalam sistem pemerintahan negara; (b) Dasar pemeliharaan dan pengembangan prinsip-prinsip pemerintahan asli; (c) Dasar Kebhinekaan; (d) Dasar negara hukum. ${ }^{41}$ Sementara itu, Josef Riwu Kaho mengemukakan ada 4 (empat) faktor yang menentukan hubungan pusat dan daerah yakni : hubungan kewenangan, hubungan keuangan, hubungan pengawasan dan hubungan yang timbul dari susunan organisasi pemerintahan di daerah. $^{42}$

Dari empat faktor ini, Eko Prasojo menyatakan faktor utama yang menentukan dalam menjaga harmonisasi dan sinergitas pusat dan daerah adalah pembagian kewenangan (urusan) antartingkatan pemerintahan. ${ }^{43}$ Apabila pembagian urusan antar keduanya jelas dan terumuskan dengan baik, maka kedudukan negara kesatuan dengan sistem desentralisasi semakin solid dan kokoh. Hal ini dikarenakan sentralisasi dan desentralisasi dalam suatu bangunan negara ditentukan oleh seberapa jauh kewenangan (urusan) yang dimiliki oleh pemerintah pusat dan pemerintah daerah. Pendulum sentralisasi dan desentralisasi sangat ditentukan oleh cara dan jenis kewenangan yang dimiliki oleh setiap level pemerintahan.

Hanif Nurcholis mengungkapkan model lain dalam penyerahan wewenang pemerintah pusat kepada pemerintah daerah. Ada dua macam model yakni : (a) Ultra Vires doctrine yaitu pemerintah pusat menyerahkan kewenangan kepada pemerintahan kepada daerah otonom dengan cara merinci satu persatu. Daerah otonom hanya boleh menyelenggarakan wewenang yang diserahkan tersebut. Sisa kewenangan dari kewenangan yang diserahkan kepada daerah otonom secara terperinci tersebut tetap menjadi kewenangan pemerintah pusat; (b) Open end arrangement atau general competence yaitu daerah otonom boleh menyelenggarakan semua urusan di luar yang dimiliki pusat. Artinya pusat menyerahkan kewenangan pemerintahan kepada daerah untuk menyelenggarakan kewenangan berdasarkan kebutuhan dan inisiatifnya sendiri di luar kewenangan yang dimiliki pusat. ${ }^{44}$

Model hubungan kewenangan antara pemerintah pusat dan daerah menurut Clarke dan Stewart dapat dibagi menjadi tiga model yaitu model relatif, model

40 Sri Nur Hari Susanto, Desentralisasi Asimetris dalam Konteks Negara Kesatuan, Administrative Law \& Governance Journal, Volume 2 Issue 4, November 2019, hlm.636.

${ }^{41}$ Bagir Manan, Op.Cit, hlm. 40.

42 Josef Riwu Kaho, Analisis Hubungan Pemerintah Pusat dan Daerah di Indonesia, Penerbit Center for Politics and Government (PolGov) Fisipol UGM, 2012, hlm.29

43 Eko Prasojo, Reformasi Kedua: Melanjutkan Estafet Reformasi, Penerbit Salemba Humanika, Jakarta, 2009, hlm. 143.

44 Hanif Nurcholis, Teori dan Praktik Pemerintahan dan Otonomi Daerah, Penerbit Gramedia, Jakarta, 2007, hlm. 156 
agensi dan model interaksi. Pertama, The Relative Autonomy Model, memberikan kebebasan pada pemerintah daerah dan pada saat yang sama tidak mengingkari realitas negara bangsa. Penekanannya adalah memberikan kebebasan bertindak pada pemerintah daerah dalam rangka kerja kekuasaan/tugas dan tanggung jawab yang telah dirumuskan oleh peraturan perundang-undangan. Kedua, The Agency Model. Model ini menempatkan pemerintah daerah tidak mempunyai kekuasaan yang cukup berarti sehingga keberadaannya terlihat sebagai agen pemerintah pusat yang bertugas untuk menjalankan kebijaksanaan pemerintah pusat. Karenanya, pada model ini berbagai petunjuk rinci dalam peraturan perundangundangan sebagai mekanisme kontrol sangat menonjol. Pada model ini, pendapatan asli daerah bukanlah hal penting dan sistem keuangan daerahnya didominasi oleh bantuan dari pemerintah pusat. Ketiga, The Interaction model, merupakan suatu bentuk model dimana keberadaan dan peran pemerintah daerah ditentukan oleh interaksi yang terjadi antara pemerintah pusat dan pemerintah daerah.

Dari sekian model hubungan pusat dan daerah yang disampaikan sejumlah teori di atas, hal yang menentukan adalah bagaimana pengaturannya pada hukum positif sebuah negara. Dalam hal ini, luas sempitnya urusan-urusan yang diserahkan kepada pemerintahan daerah sangat ditentukan pembagian urusan yang telah diatur dalam peraturan perundang-undangan yang khusus mengenai Pemerintahan Daerah. Untuk Indonesia, pengaturan itu kini tertuang dalam dalam Undang-Undang Nomor 23 Tahun 2014 tentang Pemerintahan Daerah (UU No 23 Tahun 2014) sebagai pengganti dari Undang-Undang Nomor 32 Tahun 2004 tentang Pemerintahan Daerah (UU No 32 Tahun 2004). UU No 23 Tahun 2014 juga telah mengalami perubahan hingga kedua kali, yakni ketika pada 18 Maret 2015 Presiden Joko Widodo mengesahkan Undang-Undang Nomor 9 Tahun 2015 tentang Perubahan Kedua Atas Undang-Undang Nomor 23 Tahun 2014 tentang Pemerintahan Daerah.

UU No 23 Tahun 2014 ini memberikan landasan baru dalam menata hubungan Pemerintah Pusat dan Pemerintah Daerah. Landasan baru ini berupa penetapan Urusan Wajib Daerah, dan pola hubungan Urusan Konkuren antara Pemerintah Pusat, Provinsi dan Kabupaten/Kota yang langsung dimasukkan dalam Lampiran UU No 23 Tahun 2014. Hal ini berbeda dengan UU No 32 Tahun 2004 dimana pengaturan dan penetapan urusan itu diatur lebih detail dalam Peraturan Pemerintah Nomor 38 Tahun 2007 (PP No 38 Tahun 2007).

UU No 23 Tahun 2014 membagi urusan pemerintahan menjadi tiga urusan yakni : (a) Urusan pemerintahan absolut adalah urusan pemerintahan yang sepenuhnya menjadi kewenangan pemerintah pusat; (b) urusan pemerintahan konkuren adalah urusan pemerintahan yang dibagi antara pemerintah pusat dan daerah provinsi dan daerah kabupaten/kota; (c) urusan pemerintahan umum adalah urusan pemerintahan yang menjadi kewenangan presiden sebagai kepala pemerintahan. Pelaksanaannya dapat dilimpahkan kepada gubernur dan bupati/walikota di wilayahnya masing-masing.

Pembagian tiga urusan ini menimbulkan hubungan yang baru antara pemerintah pusat dan pemerintah daerah. Hubungan baru ini menyangkut adanya skala prioritas urusan pemerintahan yang harus dilaksanakan, termasuk kontrol 
oleh pemerintah pusat. ${ }^{45}$ Dalam hal ini, pembagian kewenangan itu dikontrol dengan menerapkan norma, prosedur, dan kriteria (NPSK) dalam rangka penyelenggaraan urusan pemerintahan; dan pemerintah pusat melaksanakan pembinaan dan pengawasan terhadap penyelenggaraan Urusan Pemerintahan yang menjadi kewenangan Daerah.

Pasal 10 ayat (1) UU No 23 Tahun 2014 menyatakan urusan pemerintahan absolut itu meliputi: (a) politik luar negeri; (b) pertahanan; (c) keamanan; (d) yustisi; (e) moneter dan fiskal; (f) dan agama. Sedangkan urusan pemerintahan konkuren masih dibagi menjadi Urusan Pemerintahan Wajib dan Urusan Pemerintahan pilihan. Urusan Pemerintahan wajib terdiri dari Urusan Pemerintahan yang berkaitan dengan Pelayanan Dasar dan Non Pelayanan Dasar. Urusan Pemerintahan Wajib yang berkaitan dengan Pelayanan Dasar tersebut adalah urusan Pemerintahan Wajib yang sebagian substansinya merupakan Pelayanan Dasar.

Pasal 12 ayat (1) UU No 23 Tahun 2014 menjelaskan Urusan Pemerintahan Wajib yang berkaitan dengan pelayanan dasar meliputi: (a) pendidikan; (b) kesehatan; (c) pekerjaan umum dan penataan ruang; (d) perumahan dan kawasan permukiman; (e) kententraman, ketertiban umum dan perlindungan masyarakat; dan (f) sosial. Sedangkan Pasal 12 ayat (2) Urusan Pemerintahan yang tidak terkait dengan pelayanan dasar meliputi delapan belas urusan antara lain: (a) urusan tenaga kerja; (b) pemberdayaan perempuan dan perlindungan anak; (c) pangan; (d) , pertanahan; (e) lingkungan hidup; (f) administrasi kependudukan dan catatan sipil; (g) pemberdayaan masyarakat dan desa; (h) pengendalian penduduk dan keluarga berencana; (i) perhubungan; (j) komunikasi dan informatika; (k) koperasi, usaha kecil dan menengah; (l) penanaman modal; (m) kepemudaan dan olahraga; (n) statistik; (o) persandian; (p) kebudayaan; (q) perpustakaan; dan (r) kearsipan.

Sedangkan untuk urusan pemerintahan konkuren yang kategori pilihan meliputi: (a) kelautan dan perikanan; (b) pariwisata; (c) pertanian; (d) kehutanan; (e) energi dan sumber daya mineral; (f) perdagangan, perindustrian, dan transmigrasi.

\section{Pergeseran Peran Pemerintahan Daerah}

Arah baru UU No 23 Tahun 2014 mengenai pembagian urusan antara pemerintah pusat dan pemerintah daerah memang bertujuan untuk menata keseimbangan tanggung jawab antar tingkatan/susunan pemerintahan dalam menyelenggarakan urusan pemerintahan. Hal ini membawa beberapa konsekuensi dan arah kebijakan yang cenderung sentralisasi. Yusdianto menyebut arah kebijakan di UU No 23 Tahun 2014 lebih mengarah ke arah sentralisasi dengan berbalut konsentrasi. Hal ini terjadi karena hubungan kewenangan antara pusat

45 Septi Nur Wijayanti, Hubungan Antara Pusat dan Daerah Dalam Negara Kesatuan Republik Indonesia Berdasarkan Undang-Undang Nomor 23 Tahun 2014, Jurnal Media Hukum Vol.23. No. 2/Desember 2016., hlm.188 
dan daerah tidak sesuai dengan kehendak UUD $1945 .{ }^{46}$ Pergeseran ke sentralisasi itu diperkuat oleh Indra Perwira yang menitikberatkan pada aspek pengawasan terhadap hubungan kewenangan. Menurutnya, pengawasan preventif cenderung dilaksanakan terlalu ketat. ${ }^{47}$

Jika dicermati ketentuan pada Pasal 5 UU No 23 Tahun 2014 mengandung makna bahwa Presiden memegang kekuasaan dalam penyelenggaraan pemerintahan termasuk penyelenggaraan pemerintahan di daerah (cetak miring penulis). ${ }^{48}$ Meskipun di akhir rumusan yakni menyebutkan asas desentralisasi, dekonsentrasi dan tugas pembantuan. Makna penyelenggaraan pemerintahan di daerah mengandung prinsip dasar yang hampir sama dengan UU No 5 Tahun 1974 tentang Pemerintahan di Daerah. Dari makna ini, menunjukkan Presiden sebagai pemegang kekuasaan berwenang mengatur pemerintahan di daerah, bukan mengatur pemerintahan daerah. ${ }^{49}$ Ketentuan ini menjadi ciri penting arah kebijakan pemerintahan daerah yang pendulumnya mulai ditarik ke pemerintah pusat. Padahal Pasal 18 ayat (7) UUD 1945 menegaskan bahwa susunan dan tata cara penyelenggaraan pemerintahan daerah diatur dalam undang-undang.

Analisis terhadap UU No 23 Tahun 2014 berjalan linear terhadap peraturan perundang-undangan yang mengatur persoalan penanganan pandemi Covid-19. Dalam menangani pandemi Covid-19 ini, pemerintah mengeluarkan serangkaian regulasi baik itu peraturan sebelum tahun 2020, maupun peraturan yang baru dikeluarkan untuk menangani pandemi Covid-19 ini.

Adapun rangkaian regulasi itu antara lain: (1) Undang-Undang Nomor 4 Tahun 1984 tentang Wabah Penyakit Menular; (2) Undang-Undang Nomor 24 Tahun 2007 tentang Penanggulangan Bencana; (3) Undang-Undang Nomor 36 Tahun 2009 tentang Kesehatan; (4) Undang-Undang Nomor 6 Tahun 2018 tentang Kekarantinaan Kesehatan; (5) Peraturan Presiden Nomor 17 Tahun 2018 tentang Penyelenggaraan Kedaruratan Bencana pada Kondisi Tertentu; (6) Peraturan Pemerintah Pengganti Undang-Undang No 1 Tahun 2020 tentang Kebijakan Keuangan Negara dan Stabilitas Sistem Keuangan untuk Penanganan Pandemi Corona Virus Disease 2019 (Covid-19) dan/atau Dalam Rangka Menghadapi Ancaman yang Membahayakan Perekonomian Nasional dan/atau Stabilitas Sistem Keuangan (Perppu No 1/2020); (7), Peraturan Pemerintah No 21

46 Yusdianto, Hubungan Kewenangan Pusat dan Daerah Menurut Undang-Undang Nomor 23 Tahun 2014 tentang Pemerintahan Daerah, PADJAJARAN Jurnal Ilmu Hukum Volume 2 Nomor 3 Tahun 2015, hlm. 501-502.

${ }^{47}$ Indra Perwira, Konstitusionalitas UU No 23 Tahun 2014 tentang Pemerintahan Daerah, PADJAJARAN Jurnal Ilmu Hukum Volume 2 Nomor 3 Tahun 2015, hlm. 461.

48 Isi dari Pasal 5 UU No 23 Tahun 2014 tentang Pemerintahan Daerah adalah : (1) Presiden Republik Indonesia memegang kekuasaan pemerintahan sesuai dengan Undang-Undang Dasar Negara Republik Indonesia Tahun 1945; (2) Kekuasaan pemerintahan sebagaimana dimaksud pada ayat (1) diuraikan dalam berbagai Urusan Pemerintahan; (3) Dalam menyelenggarakan Urusan Pemerintahan sebagaimana dimaksud pada ayat (2), Presiden dibantu oleh menteri yang menyelenggarakan Urusan Pemerintahan tertentu; dan (4) Penyelenggaraan Urusan Pemerintahan sebagaimana dimaksud pada ayat (2) di Daerah dilaksanakan berdasarkan asas desentralisasi, Dekonsentrasi, dan Tugas Pembantuan.

${ }^{49}$ Otong Rosadi, Konstitusionalitas Pengaturan Pemerintahan Daerah di Indonesia: Suatu Eksperimen yang Tidak Kunjung Selesai, PADJAJARAN Jurnal Ilmu Hukum, Volume 2 Nomor 3 Tahun 2015, hlm. 438. 
Tahun 2020 tentang Pembatasan Sosial Berskala Besar Dalam Rangka Percepatan Penanganan Corona Virus Disease 2019 (Covid-19) selanjutnya disebut (PP No 21/2000); (8) Keputusan Presiden No 7 Tahun 2020 tentang Gugus Tugas Percepatan Penanganan Corona Virus Disease 2019 (Covid-19) yang telah diubah menjadi Keputusan Presiden No 9 Tahun 2020; (9) , Keputusan Presiden No 11 Tahun 2020 tentang Penetapan Kedaruratan Kesehatan Masyarakat Corona Virus Disease 2019 (Covid-19); (10) Keputusan Presiden Nomor 12 Tahun 2020 tentang penetapan bencana non alam penyebaran Corona Virus Disease 2019 (COVID-19) sebagai Bencana Nasional; (11) Instruksi Presiden Nomor 4 Tahun 2020 tentang refocussing kegiatan, realokasi anggaran serta pengadaan barang dan jasa dalam rangka percepatan penanganan Corona Virus Disease 2019 (COVID19); (12) Peraturan Menteri Dalam Negeri Nomor 20 Tahun 2020 tentang Percepatan Penanganan Corona Virus Disease 2019 di Lingkungan Pemerintah Daerah : (13) Peraturan Menteri Kesehatan Nomor 9 Tahun 2020 tentang Pedoman Pembatasan Sosial Berskala Besar Dalam Rangka Percepatan Penanganan Corona Virus Disease 2019 (Covid-19).

Dari serangkaian regulasi di atas, hal-hal yang menyangkut mengenai peran pemerintah daerah dan pengelolaan hubungan pusat dan daerah dikaji dalam bentuk tabel berikut ini:

\section{Tabel 1. Analisa Regulasi Penanganan Covid-19 Berkaitan dengan Pemerintahan Daerah}

\begin{tabular}{|c|c|c|}
\hline $\begin{array}{c}\text { Regulasi } \\
\text { Penanganan } \\
\text { Pandemi Covid-19 }\end{array}$ & Analisis & $\begin{array}{c}\text { Model Hubungan } \\
\text { Kewenangan/Urusan } \\
\text { Daerah }\end{array}$ \\
\hline UU No 4/1984 & $\begin{array}{l}\text { Ada kewajiban bagi Pemerintah } \\
\text { Daerah untuk melaksanakan tindakan } \\
\text { penanggulangan untuk mencegah } \\
\text { penyakit menular. }\end{array}$ & $\begin{array}{lr}\text { Menggunakan } & \text { The } \\
\text { Relative } & \text { Autonomy } \\
\text { Model } & \text { bersifat } \\
\text { hierarkis } & \end{array}$ \\
\hline UU No 24/2007 & $\begin{array}{l}\text { UU ini memberi peran dan } \\
\text { kewenangan kepada pemda untuk } \\
\text { menetapkan kebijakan, pembuatan } \\
\text { perencanaan, pelaksanaan kebijakan } \\
\text { kerjasama dalam penanggulangan } \\
\text { bencana pada wilayah masing-masing } \\
\text { daerah memberikan perlindungan } \\
\text { masyarakat, menjamin pemenuhan } \\
\text { hak masyarakat dan pengungsi. }\end{array}$ & $\begin{array}{l}\text { Pelaksanaan urusan } \\
\text { pemerintahan wajib } \\
\text { yang berkaitan dengan } \\
\text { pelayanan dasar yakni } \\
\text { ketentraman, ketertiban } \\
\text { umum dan perlindungan } \\
\text { masyarakat dan urusan } \\
\text { sosial.Meski begitu, ada } \\
\text { urusan yang tidak } \\
\text { berkaitan dengan non } \\
\text { pelayanan dasar yang } \\
\text { menjadi tanggung jawab } \\
\text { pemda yakni } \\
\text { pemberdayaan } \\
\text { perempuan } \\
\text { perlindungan anak, } \\
\text { pertanahan, lingkungan } \\
\text { hidup }\end{array}$ \\
\hline
\end{tabular}




\begin{tabular}{|c|c|c|}
\hline UU No $6 / 2018$ & $\begin{array}{l}\text { UU ini memberikan penekanan atas } \\
\text { tanggung jawab Pemda dalam } \\
\text { penyelenggaraan Kekarantinaan } \\
\text { Kesehatan. Pemda sama sekali tidak } \\
\text { mempunyai wewenang. Arah UU ini } \\
\text { memberikan kewenangan besar } \\
\text { kepada pemerintah pusat untuk } \\
\text { menetapkan Kedaruratan Kesehatan } \\
\text { Masyarakat, Karantina Wilayah, atau } \\
\text { Pembatasan Sosial Berskala Besar }\end{array}$ & $\begin{array}{ll}\text { Menempatkan } & \\
\text { Pemerintah } & \text { Daerah } \\
\text { sebagai The } & \text { Agency } \\
\text { Model. } & \\
\text { Pelaksanaan } & \text { tugas } \\
\text { pembantuan } & \text { lebih } \\
\text { dikedepankan. } & \end{array}$ \\
\hline $\begin{array}{l}\text { Perppu No } 1 \text { Tahun } \\
2020\end{array}$ & $\begin{array}{l}\text { Dasar kewenangan bagi Pemda untuk } \\
\text { refocusing keuangan daerah dari } \\
\text { Anggaran Pendapatan dan Belanja } \\
\text { Daerah untuk penanganan Pandemi } \\
\text { Covid-19. }\end{array}$ & $\begin{array}{l}\text { Menempatkan } \\
\text { Pemerintah } \\
\text { sebagai The } \\
\text { Model }\end{array}$ \\
\hline PP No 2 & $\begin{array}{l}\text { Dalam konsideran, UU } 23 \text { Tahun } \\
2014 \text { tentang Pemerintah Daerah } \\
\text { sama sekali tidak dicantumkan. } \\
\text { Daerah hanya berhak mengusulkan } \\
\text { untuk mengajukan PSBB. } \\
\text { Peraturan ini sama sekali kurang } \\
\text { mengelaborasi lebih detail tentang } \\
\text { kewenangan pemerintah daerah dalam } \\
\text { penanganan Covid. }\end{array}$ & $\begin{array}{l}\text { Model hubungan yang } \\
\text { ditekankan adalah The } \\
\text { Agency Model. } \\
\text { Pembagian urusan } \\
\text { pemerintahan konkuren } \\
\text { Wajib yang berkaitan } \\
\text { dengan pelayanan dasar } \\
\text { dan non pelayanan dasar } \\
\text { Pelaksanaan tugas } \\
\text { pembantuan lebih } \\
\text { dikedepankan }\end{array}$ \\
\hline $\begin{array}{l}\text { Permendagri No 20/ } \\
2020\end{array}$ & $\begin{array}{l}\text { Dasar bagi Pemda untuk mengelola } \\
\text { pengeluaran yang belum tersedia } \\
\text { anggarannya untuk dimasukkan } \\
\text { dalam pembebanan langsung pada } \\
\text { belanja tidak terduga. }\end{array}$ & $\begin{array}{ll}\text { Pelaksanaan } & \text { tugas } \\
\text { pembantuan } & \text { lebih } \\
\text { dikedepankan } & \end{array}$ \\
\hline $\begin{array}{c}\text { Permenkes No } \\
9 / 2020\end{array}$ & $\begin{array}{l}\text { Pengajuan permohonan bagi daerah } \\
\text { yang ingin menerapkan Pembatasan } \\
\text { Sosial Berskala Besar (PSBB), } \\
\text { termasuk bentuk pembatasan- } \\
\text { pembatasan terhadap sekolah, } \\
\text { kegiatan keagamaan, kegiatan sosial } \\
\text { dan budaya, kegiatan di tempat } \\
\text { fasilitas umum mekanisme daerah } \\
\text { yang ingin }\end{array}$ & $\begin{array}{l}\text { Model hubungan yang } \\
\text { ditekankan adalah The } \\
\text { Agency Model }\end{array}$ \\
\hline $\begin{array}{l}\text { Keppres No } 9 \text { Tahun } \\
2020 \text { tentang } \\
\text { Perubahan Atas } \\
\text { Keputusan Presiden } \\
\text { No } 7 \text { Tahun } 2020 .\end{array}$ & $\begin{array}{l}\text { UU No } 23 \text { Tahun } 2014 \text { tentang } \\
\text { Pemerintahan Daerah sama sekali } \\
\text { diabaikan dalam konsiderans. } \\
\text { Penugasan kepada Gubernur dan } \\
\text { Bupati/Walikota untuk membentuk } \\
\text { Gugus Tugas Percepatan Penanganan } \\
\text { Covid-19 berdasarkan pertimbangan } \\
\text { dan rekomendasi Ketua Gugus Tugas. } \\
\text { Untuk penanganan mengikuti arahan } \\
\text { Ketua Gugus Tugas. }\end{array}$ & $\begin{array}{l}\text { Gubernur dan } \\
\text { Bupati/Walikota } \\
\text { menjadi ketua gugus } \\
\text { Penanganan Covid-19 di } \\
\text { Daerah. Di samping itu, } \\
\text { Kedudukan Gubernur } \\
\text { sebagai anggota Dewan } \\
\text { Pengarah Gugus Tugas } \\
\text { Covid-19 Tingkat } \\
\text { Nasional diatur dalam }\end{array}$ \\
\hline
\end{tabular}




\begin{tabular}{|c|c|c|}
\hline & $\begin{array}{l}\text { Gubernur dan Bupati/Walikota sama } \\
\text { sekali tidak masuk dalam struktur } \\
\text { susunan keanggotaan gugus tugas }\end{array}$ & $\begin{array}{lr}\text { Surat Edaran } & \text { Menteri } \\
\text { Dalam Negeri } & \text { No. } \\
\text { 440/2622/SJ } & \text { tentang } \\
\text { Pembentukan } & \text { Gugus } \\
\text { Tugas } & \text { Percepatan } \\
\text { Penanganan } & \text { Corona } \\
\text { Virus Disease } & 2019 \\
\text { (Covid-19) } & \text { Daerah. } \\
\text { Gubernur atau Bupati } \\
\text { /Walikota }\end{array}$ \\
\hline $\begin{array}{l}\text { Surat Edaran Menteri } \\
\text { Dalam Negeri No. } \\
\text { 440/2622/SJ tentang } \\
\text { Pembentukan Gugus } \\
\text { Tugas Percepatan } \\
\text { Penanganan Corona } \\
\text { Virus Disease } 2019 \\
\text { (Covid-19) Daerah. }\end{array}$ & $\begin{array}{l}\text { Arahan bagi kepala daerah sebagai } \\
\text { ketua gugus tugas penanganan covid- } \\
19 \text { Daerah dalam penyusunan susunan } \\
\text { organisasi, keanggotaan untuk } \\
\text { berpedoman pada SE Mendagri ini. } \\
\text { Pemberian kewenangan bagi daerah } \\
\text { untuk menetapkan status keadaan } \\
\text { darurat siaga bencana Covid-19 } \\
\text { dan/atau keadaan tanggap darurat } \\
\text { bencana Covid-19 di tingkat provinsi } \\
\text { dan/atau kabupaten/kota. }\end{array}$ & 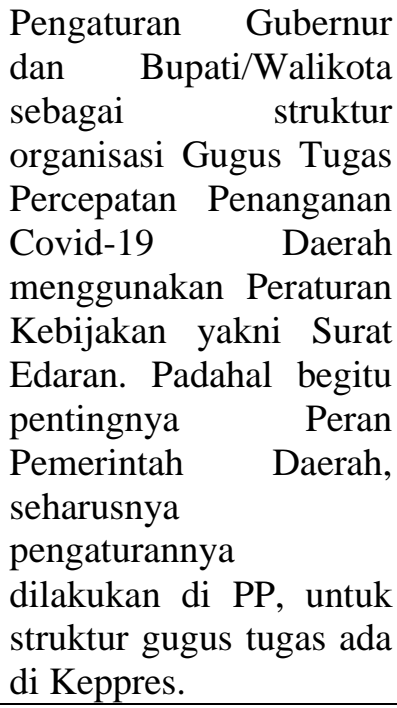 \\
\hline
\end{tabular}

\section{PENUTUP}

Berdasarkan pemaparan di atas, dapat disimpulkan bahwa prinsip dasar yang digunakan dalam pengelolaan hubungan Pemerintah Pusat dan Pemerintah Daerah itu adalah berbasis desentralisasi sebagaimana arah kebijakan otonomi daerah. Namun, dalam perkembangannya seiring adanya pengaturan baru dalam UU No 23 Tahun 2014 tentang Pemerintahan Daerah, pendulum pengelolaan hubungan pusat dan daerah ini bergeser ke arah sentralisasi. Hal ini berpengaruh terhadap model hubungan antara Pemerintah Pusat dan Pemerintah Daerah yang secara teoritis lebih banyak menempatkan Pemerintah Daerah sebagai The Agency Model. Model ini menempatkan pemerintah daerah tidak mempunyai kekuasaan yang berarti sehingga keberadaannya sebagai agen pemerintah pusat yang bertugas untuk menjalankan kebijaksanaan pemerintah pusat. Model hubungan ini ternyata berpengaruh dalam mengelola hubungan pusat dan daerah selama masa pandemi Covid-19. Sejumlah regulasi yang berkaitan dengan penanganan Pandemi Covid-19 telah memposisikan Pemerintah Daerah untuk melaksanakan tugas pembantuan. Padahal dalam penanganan pandemi Covid-19, ujung tombak penyelesaian ada di Pemerintahan Daerah. Sejumlah Urusan Pemerintahan yang menjadi urusan dari Pemerintah Daerah Kabupatan/Kota harus dimaksimalkan untuk menangani Covid-19 ini dengan memberikan keleluasaan atau diskresi untuk melakukan langkah-langkah strategi dalam upaya pencegahan dan penanganan Covid-19. 


\section{DAFTAR PUSTAKA}

\section{Buku}

Asshiddiqie, Jimly, 2012, Pengantar Ilmu Hukum Tata Negara, Rajawali Pers, Jakarta.

Asshiddiqie, Jimly, Konstitusi dan Konstitusionalisme Indonesia, Sinar Grafika, Jakarta.

Huda, Ni'matul, 2011, Hukum Tata Negara Indonesia, Edisi Revisi, Rajawali Pers, Jakarta, Cetakan Keenam.

Huda, Ni'matul, Otonomi Daerah; Filosofi, Sejarah Perkembangan dan Problematika, Pustaka Pelajar, Yogyakarta.

HR, Ridwan, 2009, Hukum Administrasi di Daerah, FH UII Press, Yogyakarta.

Hadjon, Philipus M, 1993, Pengantar Hukum Administrasi Indonesia, Penerbit Gajah Mada University Press, Yogyakarta.

Hendratno, Edie Toet, 2009, Negara Kesatuan, Desentralisasi, dan Federalisme, Graha Ilmu, Yogyakarta.

Kaho, Josef Riwu, 2012, Analisis Hubungan Pemerintah Pusat dan Daerah di Indonesia, Penerbit Center for Politics and Government (PolGov) Fisipol UGM.

Kaloh, J, 2007, Mencari Bentuk Otonomi Daerah: Suatu Solusi Dalam Menjawab Kebutuhan Lokal dan Tantangan Global, Penerbit Rineka Cipta, 2007.

Lubis, M. Solly, 1975, Pergeseran Garis Politik dan Perundang-undangan Mengenai Pemerintahan Daerah, Alumni, Bandung.

Manan, Bagir, 1995, Hubungan Pusat dan Daerah Menurut UUD 1945, Pustaka Sinar Harapan, Jakarta.

Marzuki, Peter Mahmud, 2011, Penelitian Hukum, Prenada Media Group, Cetakan Ke-7, November.

Nurcholis, Hanif, 2007, Teori dan Praktik Pemerintahan dan Otonomi Daerah, Penerbit Gramedia, Jakarta

Prasojo, Eko, 2009, Reformasi Kedua: Melanjutkan Estafet Reformasi, Penerbit Salemba Humanika, Jakarta.

Rauf, Rahyunir, 2018, Asas Penyelenggaraan Pemerintah Daerah: Dekonsentrasi, Desentralisasi, dan Tugas Pembantuan, Zanafa Publishing.

Sarundajang, S.H., 1999, Arus Balik Kekuasaan Pusat ke Daerah, Sinar Harapan, Jakarta.

Syaukani, et al, 2012, Otonomi Daerah dalam Negara Kesatuan, Pustaka Pelajar, Yogyakarta, Cetakan IX.

Smith, B.C., 1985, Decentralization: The Territorial Dimension of The State, London Asia Publishing House.

Supriatna, Tjahya, Sistem Administrasi Pemerintahan di Daerah, Penerbit Bumi Aksara, Jakarta.

Sirajudin, et al, 2016, Hukum Administrasi Pemerintahan Daerah, Setara Press, Malang.

Syafrudin, Ateng, 1985, Pasang Surut Otonomi Daerah, Penerbit Bina Cipta, Bandung. 
Syafrudin, Ateng, 1991, Titik Berat Otonomi Daerah pada Daerah Tingkat II dan Perkembangannya, Mandar Maju, Bandung.

\section{Jurnal}

Andryan, Harmonisasi Pemerintah Pusat dan Daerah Sebagai Efektifitas Sistem Pemerintahan, Jurnal Legislasi Indonesia, Vol. 16, No.4 - Desember 2019.

Indah, Hubungan Kewenangan Antara Pemerintah Pusat dan Daerah dalam Negara Kesatuan Republik Indonesia, Rechtidee, Jurnal Hukum, Vol.9, No.2, Desember 2014.

Kustiawan, Otonomi Daerah dan Desentralisasi Dalam Bingkai Negara Kesatuan Republik Indonesia

Nugroho, Trilaksono, Reformasi dan Reorientasi Kebijakan Otonomi Daerah dalam Perspektif Hubungan Pemerintah Pusat -Daerah, Jurnal Administrasi Negara Vol. 1 ,No 1, September 2000.

Perwira, Indra, Konstitusionalitas UU No 23 Tahun 2014 tentang Pemerintahan Daerah, PADJAJARAN Jurnal Ilmu Hukum, Volume 2 Nomor 3 Tahun 2015.

Rosadi, Otong, Konstitusionalitas Pengaturan Pemerintahan Daerah di Indonesia: Suatu Eksperimen yang Tidak Kunjung Selesai, PADJAJARAN Jurnal Ilmu Hukum, Volume 2 Nomor 3 Tahun 2015.

Saleh, Kausar Ali, Mengelola Hubungan Pemerintahan Pusat dengan Pemerintahan Daerah yang Efektif dan Efisien Dalam Politik Desentralisasi, Jurnal Ilmu Budaya, Vol.40, No.55, Maret 2017

Susanto, Sri Nur Hari, Desentralisasi Asimetris dalam Konteks Negara Kesatuan, Administrative Law \& Governance Journal, Volume 2 Issue 4, November 2019.

Wijayanti, Septi Nur, Hubungan Antara Pusat dan Daerah Dalam Negara Kesatuan Republik Indonesia Berdasarkan Undang-Undang Nomor 23 Tahun 2014, Jurnal Media Hukum Vol.23. No. 2/Desember 2016.

Wirazilmustaan, dkk, Konsep Hubunan Kewenangan Antara Pemerintahan Pusat dan Pemerintah Daerah dalam Bingkai Negara Kesatuan Dengan Corak Otonomi Luas, Jurnal Hukum Progresif: Volume XII/No.2/Desember 2018.

Yusdianto, Hubungan Kewenangan Pusat dan Daerah Menurut Undang-Undang Nomor 23 Tahun 2014 tentang Pemerintahan Daerah, PADJAJARAN Jurnal Ilmu Hukum, Volume 2 Nomor 3 Tahun 2015.

\section{Majalah/Koran}

Media Indonesia, Daerah Diminta Tidak Melenceng, Kamis, 2 April 2020.

Majalah Tempo, Buruk Data, Bansos Digelontor, Edisi 4-11 Mei 2020.

\section{Peraturan Perundang-Undangan}

Undang-Undang Nomor 4 Tahun 1984 tentang Wabah Penyakit Menular (Lembaran Negara Republik Indonesia Tahun 1984 Nomor 20, Tambahan Lembaran Negara Republik Indonesia Nomor 3273).

Undang-Undang Nomor 32 Tahun 2004 tentang Pemerintahan Daerah 
Undang-Undang Nomor 6 Tahun 2018 tentang Kekarantinaan Kesehatan (Lembaran Negara Republik Indonesia Tahun 2018 Nomor 128, Tambahan Lembaran Negara Republik Indonesia Nomor 6236).

Undang-Undang Nomor 24 Tahun 2007 tentang Penanggulangan Bencana (Lembaran Negara Republik Indonesia Tahun 2007 Nomor 66, Tambahan Lembaran Negara Republik Indonesia Nomor 4723).

Undang-Undang Nomor 23 Tahun 2014 tentang Pemerintah Daerah (Lembaran Negara Republik Indonesia Tahun 2014 Nomor 244, Tambahan Lembaran Negara Republik Indonesia Nomor 5587) sebagaimana telah diubah beberapa kali terakhir dengan Undang-Undang Nomor 9 Tahun 2015 tentang Perubahan Kedua Atas Undang-Undang Nomor 23 Tahun 2014 tentang Pemerintahan Daerah (Lembaran Negara Republik Indonesia Tahun 2015 Nomor 58, Tambahan Lembaran Negara Republik Indonesia Nomor 5679).

Peraturan Pemerintah Pengganti Undang-Undang Nomor 1 Tahun 2020 tentang Kebijakan Keuangan Negara dan Stabilitas Sistem Keuangan untuk Penanganan Pandemi Corona Virus Disease 2019 (Covid-19) dan/atau Dalam Rangka Menghadapi Ancaman yang Membahayakan Perekonomian Nasional dan/atau Stabilitas Sistem Keuangan (Lembaran Negara Republik Indonesia Tahun 2020 Nomor 87, Tambahan Lembaran Negara Republik Indonesia Nomor 6485)

Peraturan Pemerintah Nomor 21 Tahun 2020 tentang Pembatasan Sosial Berskala Besar Dalam Rangka Percepatan Penanganan Corona Virus Disease 2019 (Covid-19) (Lembaran Negara Republik Indonesia Tahun 2020 Nomor 91, Tambahan Lembaran Negara Republik Indonesia Nomor 6487).

Peraturan Menteri Kesehatan Nomor 9 Tahun 2020 tentang Pedoman Pembatasan Sosial Berskala Besar Dalam Rangka Percepatan Penanganan Corona Virus Disease 2019 (Covid-19) (Berita Negara Republik Indonesia Tahun 2020 Nomor 326)

Peraturan Menteri Dalam Negeri Nomor 20 Tahun 2020 tentang Percepatan Corona Virus Disease 2019 di Lingkungan Pemerintah Daerah (Berita Negara Republik Indonesia Tahun 2020 Nomor 249).

Keputusan Presiden Nomor 7 Tahun 2020 tentang Gugus Tugas Percepatan Penanganan Corona Virus Disease 2019 (Covid-19) sebagaimana telah diubah dengan Keputusan Presiden Nomor 9 Tahun 2020.

Instruksi Menteri Dalam Negeri Nomor 1 Tahun 2020 tentang Pencegahan Penyebaran dan Percepatan Penanganan Corona Virus Disease 2019 di Lingkungan Pemerintah Daerah.

Surat Edaran Menteri Dalam Negeri tentang Pembentukan Gugus Tugas Percepatan Penanganan Corona Virus Disease 2019 (Covid-19) Daerah. 